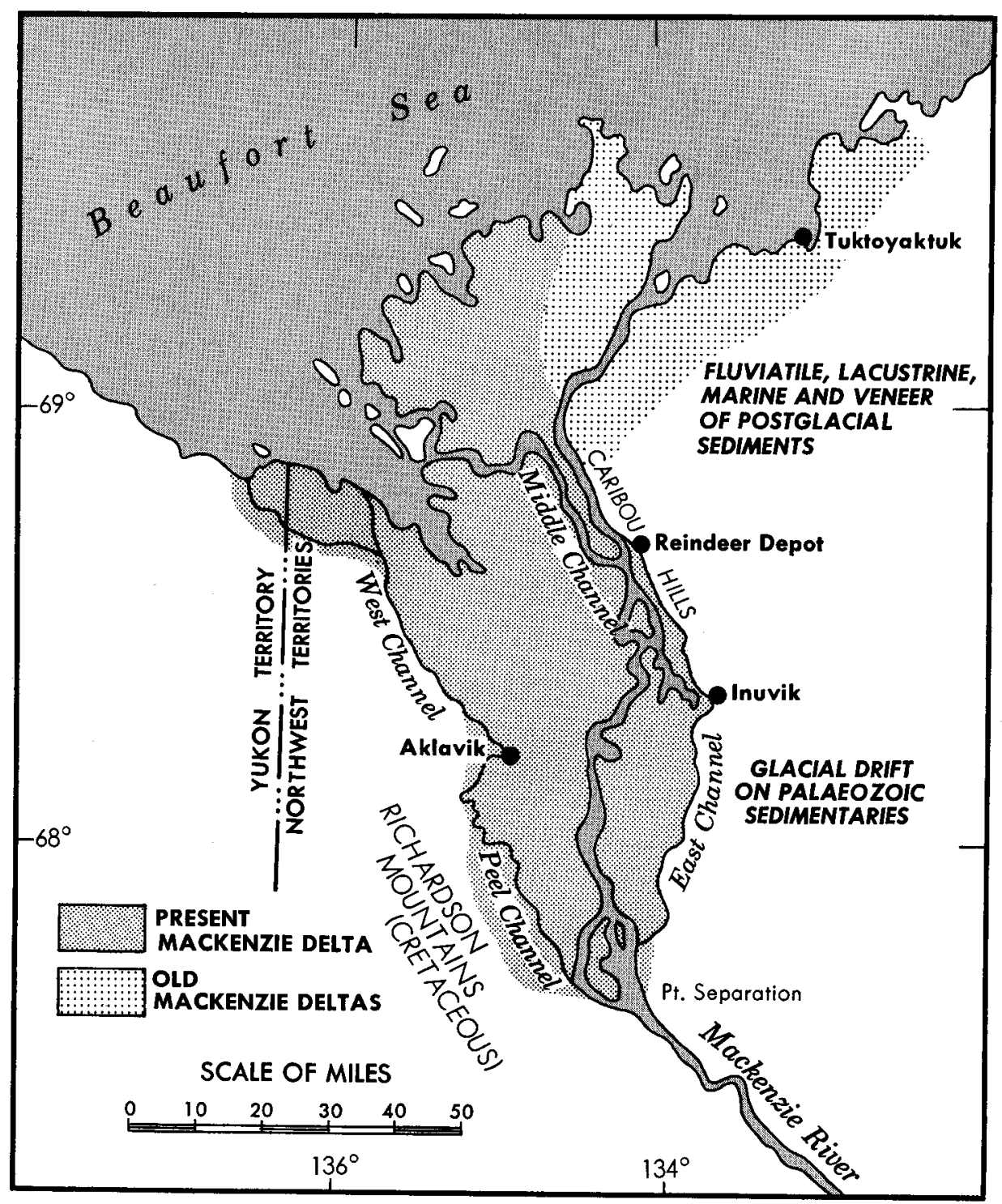

Fig. 1. The Inuvik region. 


\title{
SOME OBSERVATIONS ON PERMAFROST DISTRIBUTION AT A LAKE IN THE MACKENZIE DELTA, N.W.T., CANADA
}

\author{
G. H. Johnston* and R. J. E. Brown*
}

$\mathbf{T}$

THE THAWING effect of water in contact with permafrost is a problem of major concern to engineers engaged in northern construction. Improper drainage or disrupted natural drainage, which allows water to pond adjacent to or under structures such as buildings, roads, or airstrips, usually results in an increased depth of thaw of the perennially frozen ground. In many cases the performance of the structure is seriously affected - sometimes failure has resulted. The degradation of permafrost by water is of even greater concern when dykes or dams are constructed on perennially frozen ground and large areas are covered by the water impounded behind these embankments. The design and performance of these structures and the stability of the underlying foundation material is dependent on a knowledge of the rate at which thawing will take place and the depth to which the perennially frozen ground will thaw.

One method of improving knowledge of the thawing effect of water on permafrost and of providing some guidance for future engineering design is to study the present level of permafrost under natural bodies of water in the north, such as lakes and streams. An investigation to determine the distribution of permafrost under and adjacent to a lake in the Mackenzie Delta near the new townsite of Inuvik, N.W.T. was carried out by members of the Division of Building Research in April 1961. This study, although limited in scope, yielded interesting results, which are now reported.

\section{Some aspects of the thawing effect of water}

The occurrence and movement of surface and subsurface water exerts an important influence on the thermal regime of the ground. Because of the heat storage capacity of water, its movement from one area to another provides the means to transfer substantial amounts of thermal energy. Moving or standing bodies of water that accumulate an excess of thermal energy inhibit the formation of permafrost and cause thawing of the underlying frozen ground.

* Northern Research Group, Soil Mechanics Section, Division of Building Research, National Research Council, Ottawa, Canada. 
In permafrost areas a thawed zone is always found under lakes and streams that have a mean bottom temperature greater than $32^{\circ} \mathrm{F}$. Although lakes that are deep enough to contain some unfrozen water throughout the year have the greatest thawing effect on permafrost, lakes that freeze to the bottom during the winter, i.e., in which the mean bottom temperature is less than $32^{\circ} \mathrm{F}$., do influence and modify the thermal regime of the ground. The mean permafrost temperatures under lakes in the Point Barrow area of Alaska were found to be as much as $5.4^{\circ} \mathrm{F}$ greater than in the adjacent undisturbed terrain (Brewer 1958a). These studies also showed that lakes in that area, having a diameter of half a mile or more and a depth of at least 7 feet, could be expected to have a thawed zone below them to a depth of about 200 feet. Russian observations (Grigor'ev 1959) have shown the importance of the composition of the lake bottom on heat flow and hence on the extent of the thawed basin. Impermeable sediments restrict the convective heat exchange at the lake bottom. Their studies suggest that the thickness of the "taliks" (unfrozen zones) under lakes that do not freeze to the bottom will be proportional to the local yearly air temperature amplitude regardless of the areal extent of the lake.

The effect of rivers on thawing of permafrost is more difficult to assess because flowing water complicates the energy exchange relationships. Below the Shaviovik River in northern Alaska a warming effect of $5.4^{\circ} \mathrm{F}$ was observed in the soils to a depth of 135 feet (Brewer 1958b). Russian studies showed that the moderating influence of rivers on permafrost extended as much as 300 feet back from the river bank and produced thawed basins under the river up to 100 feet deep. It was concluded that the unfrozen zone generally takes the shape of an extended trough, the width of which is proportional to the width of the river (Grigor'ev 1959).

The influence at the edge of a large body of water such as an ocean or a very large lake depends upon the magnitude of the temperature difference between the land surface and the bottom of the water body, the thermal properties of the ground materials, and past changes in climate or shoreline configuration or both. A mathematical examination of the problem (Lachenbruch 1957) suggested that in far northern latitudes, except where there are transgressing shorelines, permafrost is not to be expected to depths greater than about 100 feet below the ocean floor at points farther than a few thousand feet off shore.

The extent of the thawed zone found under lakes and streams having a mean bottom temperature greater than $32^{\circ} \mathrm{F}$. depends on a number of factors including the thermal characteristics of the water body and the adjacent ground, the size and depth of the water body, general hydrologic condition of the body, thickness of ice and snow cover and composition and history of accumulation of bottom sediments. For most practical purposes, however, the problem can be generalized and considered in terms of surface temperature and age. Mathematical and graphical methods of analysis, which have been developed and described (and confirmed by application to actual field conditions), provide a means of estimating the temperature regime in 
the ground under bodies of water or structures erected in permafrost areas (Lachenbruch 1957b and 1962; Mackay 1962; Brown, W. G., 1962 and 1963a, b).

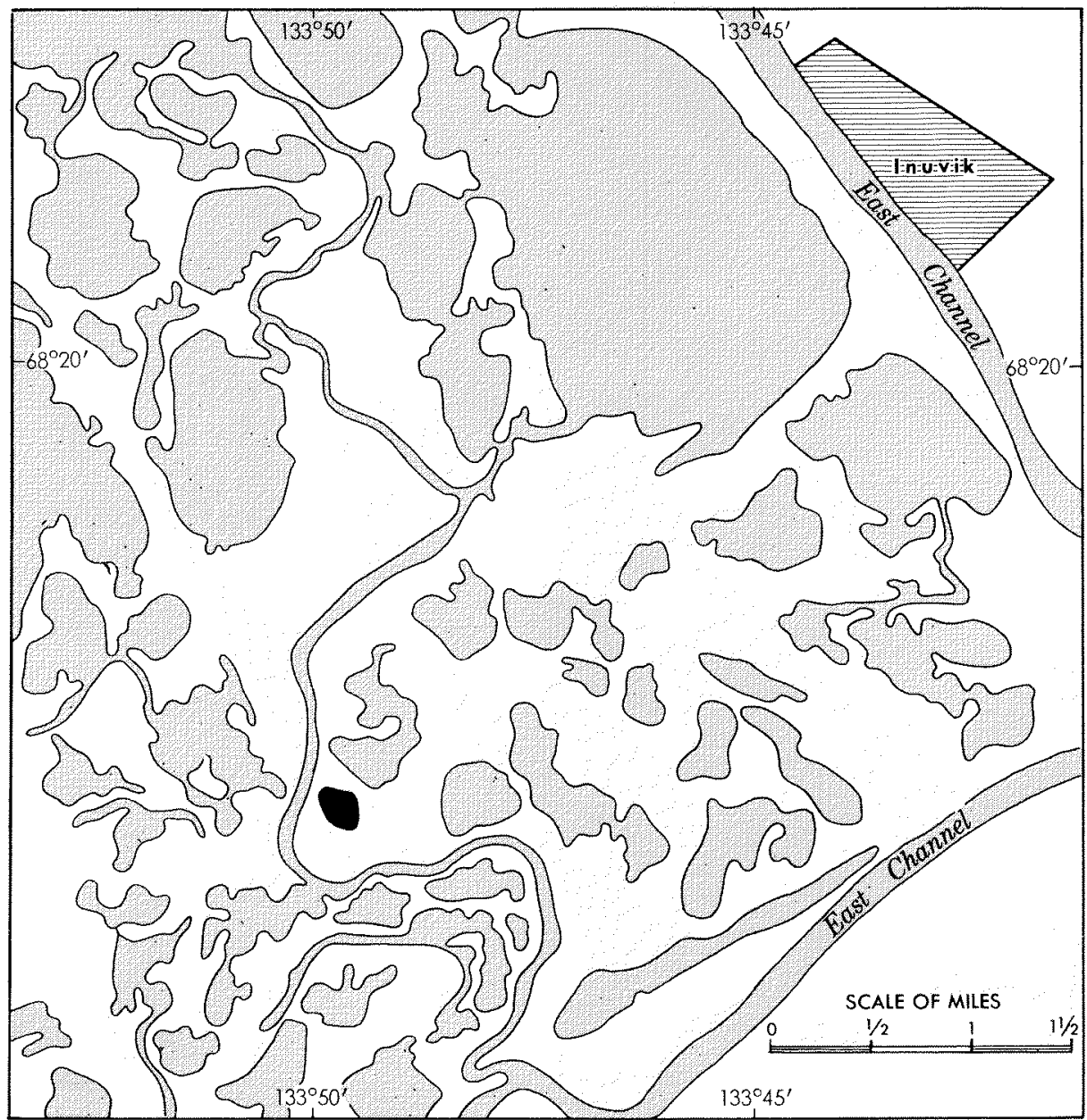

Fig. 2. Part of the Mackenzie Delta near Inuvik showing lake investigated (in black).

\section{Description of site and area}

The Mackenzie Delta is approximately 50 miles wide and 100 miles long. Inuvik is located on the East Channel on the eastern flank of the delta about half way to the arctic coast from the head of the delta at Pt. Separation (Fig. 1). The delta is a low, flat area interlaced and dissected by several large channels and numerous smaller meandering channels and is spotted with thousands of stagnant lakes. 
Weather records at Inuvik cover only a few years but observations, mostly temperature and precipitation, have been recorded for more than 30 years at Aklavik, 35 air miles to the west. The mean annual temperature at Aklavik is $16^{\circ} \mathrm{F}$, and the minimum and maximum yearly averages are $8^{\circ}$ and $24^{\circ} \mathrm{F}$. respectively. The average of the lowest temperatures in each year (32 years of observation) is $-51^{\circ} \mathrm{F}$. and the average of the highest temperatures recorded in each year is $83^{\circ} \mathrm{F}$. The total yearly precipitation at Aklavik is $9.77 \mathrm{in}$. consisting of $4.26 \mathrm{in}$. of rain and $55.1 \mathrm{in}$. of snow (10 in. of snow equivalent to $1 \mathrm{in}$. of rain).

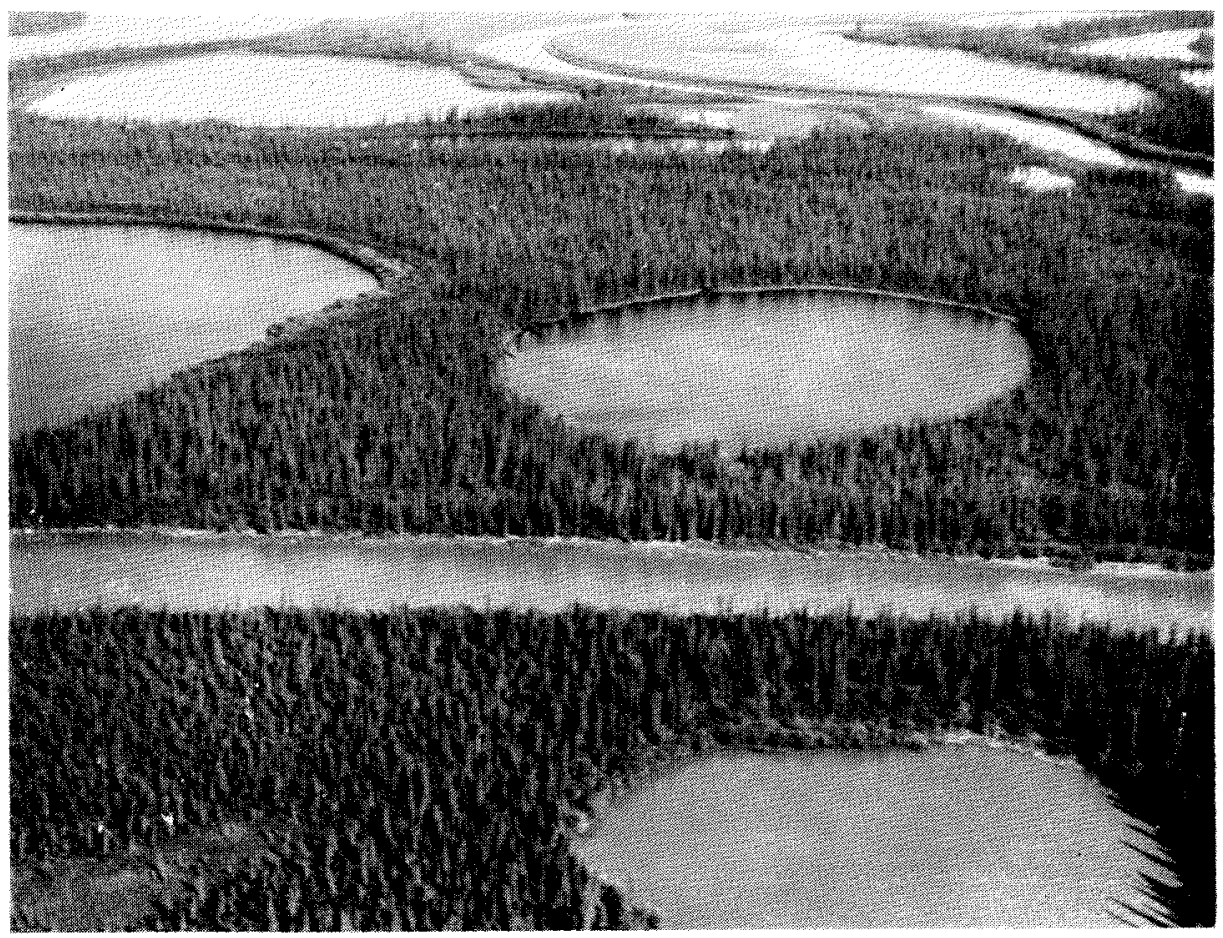

Fig. 3. Aerial view of the lake (centre right) looking east (July 1960).

A small lake in the delta was selected for investigation following a preliminary study of aerial photographs and a field reconnaissance in 1960 of a part of the delta within a 10-mile radius of Inuvik (Fig. 2). This lake, located about 5 miles southwest of the town, is approximately circular with a diameter of about $900 \mathrm{ft}$. Like all delta lakes it is shallow with a maximum water depth of about $5 \mathrm{ft}$.

The banks of the delta channels and lakes are low (10 to $20 \mathrm{ft}$.), built of alluvial material and forested with spruce and willow (Fig. 3). The dense forest vegetation around the lake studied is typical of the climax developed in the lower valley and delta of the Mackenzie River. The dominant species 
is white spruce, the largest trees growing to a height of $50 \mathrm{ft}$. Also present are black spruce, willow, and alder with scattered stands of tamarack. The largest trees in the adjacent area grow close to the edge of the lake. The apparently continuous moss cover is about 1 in. thick.

During the initial planning of the project it was considered important to choose a body of water that had been in existence for a sufficient period of time to have approached a condition of thermal equilibrium with the frozen ground underneath. It was realized that a delta lake is a special case inasmuch as it is situated in an old river bed and that the occurrence of permafrost might be affected considerably by the large number of lakes and channels in the immediate vicinity. The lake selected, however, offered a number of advantages for such a study because of homogeneous subsurface soil conditions and also relative ease of access from Inuvik during the winter.

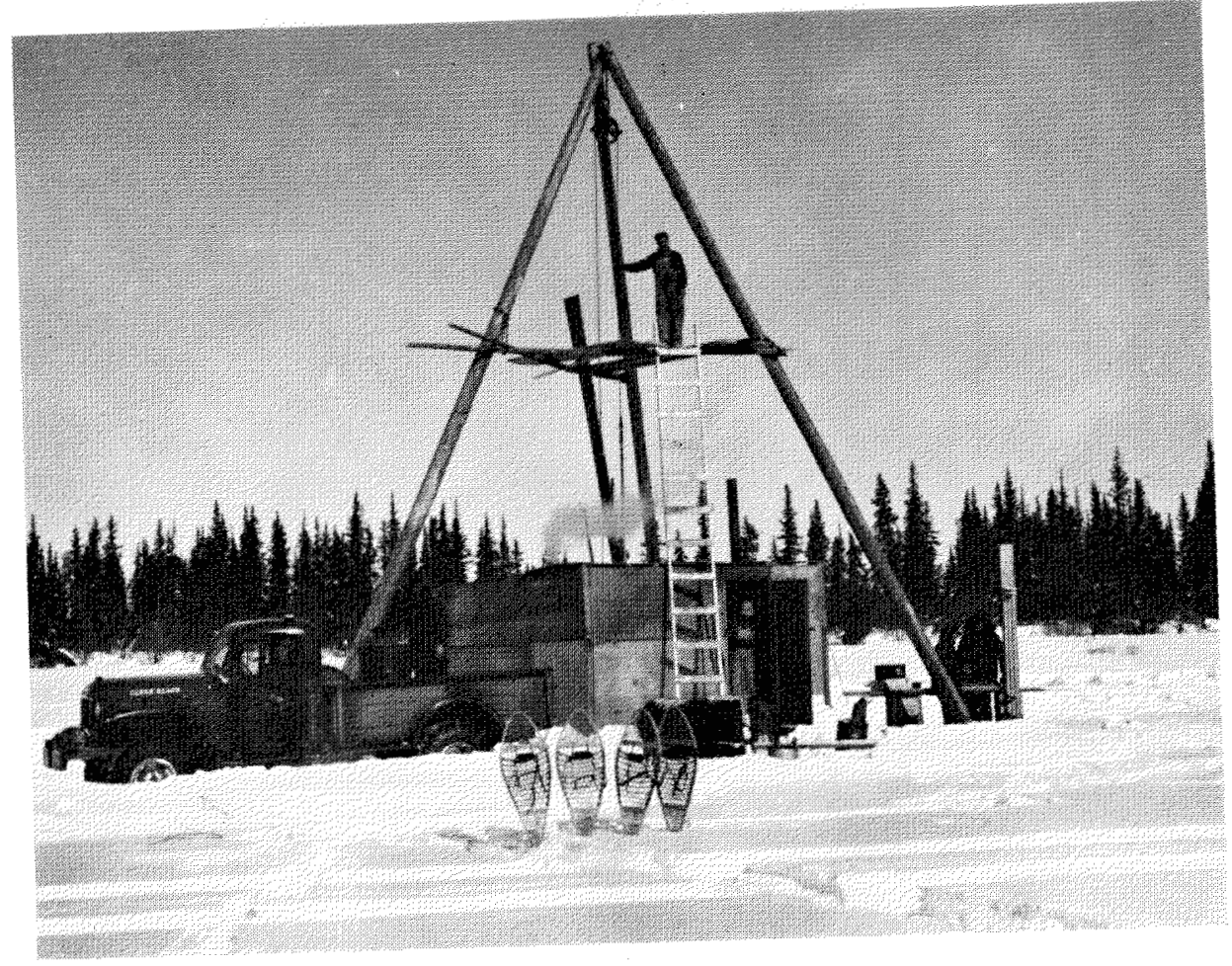

Fig. 4. Drilling rig at centre of lake, borehole No. 1 (April 1961).

\section{Scope of investigation}

The investigation consisted primarily of a drilling and sampling operation (Fig. 4) whereby holes were bored to various depths at four locations 
(Fig. 5). Hole No. 1 was drilled under the centre of the lake to bedrock at a depth of $230 \mathrm{ft}$; hole No. 2, located $33 \mathrm{ft}$. west of the edge of the lake, was drilled to $115 \mathrm{ft}$; hole No. $3,132 \mathrm{ft}$. west of the lake, was drilled to $196 \mathrm{ft}$., and hole No. 4, $550 \mathrm{ft}$. west of the lake, to bedrock at $260 \mathrm{ft}$. Continuous coring was carried out for the full depth of holes Nos. 1 and 3 and good undisturbed cores of most of the materials encountered were obtained. Representative samples were taken for identification and classification testing of the soils, moisture (ice) content determinations, pollen analysis, carbon-14 age determinations and petroleum pigment analysis.

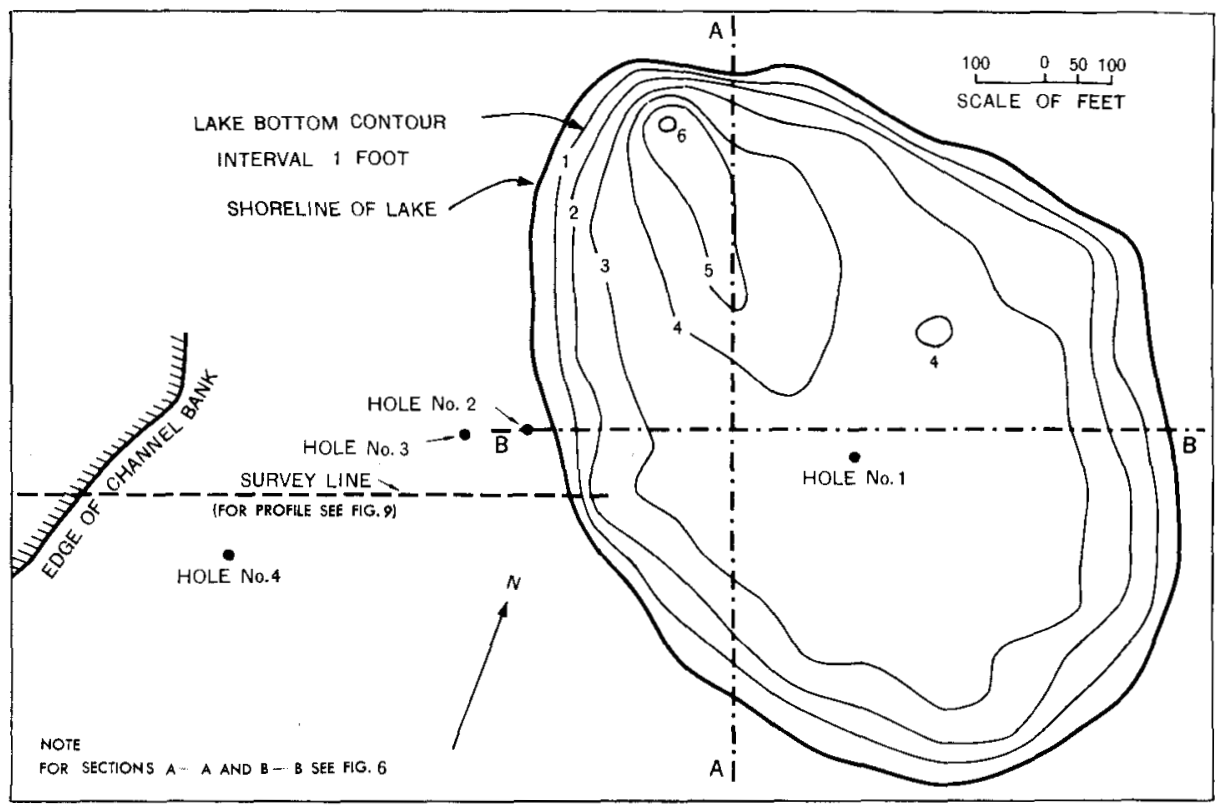

Fig. 5. Lake bottom contours and borehole locations (April 1961).

A number of hand probings were made in April 1961 and September 1962 to determine the location of the permafrost table near the edge of the lake. Level surveys were run to establish the relative altitudes of the lake and channel surfaces and adjacent areas. Surveys were also carried out on a grid pattern on the lake to obtain snow depths, lake bottom contours, ice thickness and water depths. Water samples were taken from the lake and from adjacent channels for analysis. Two thermocouple cables were installed to measure ground temperatures: one 100-foot cable was placed in hole No. 3 with sensing junctions at the 25-, 50- and 100-foot depths, and a 200-foot cable was placed in hole No. 4 with points at 5-foot intervals from the ground surface to $25 \mathrm{ft}$. and at the 50-, 75-, 100-, 150- and 200-foot depths. 


\section{Drilling and sampling}

A standard-type diamond drill equipped with hydraulic feed was used to drill and sample the various materials encountered. The presence of permafrost and the subnormal air temperatures that occurred during April greatly complicated the drilling and sampling operation. Water at a temperature of $33^{\circ}$ to $35^{\circ} \mathrm{F}$. was obtained from the lake and was used as a circulating medium except for one unsuccessful attempt to use arctic grade fuel oil. When using water, drilling techniques had to be modified slightly and great care taken to prevent freezing of equipment in the hole.
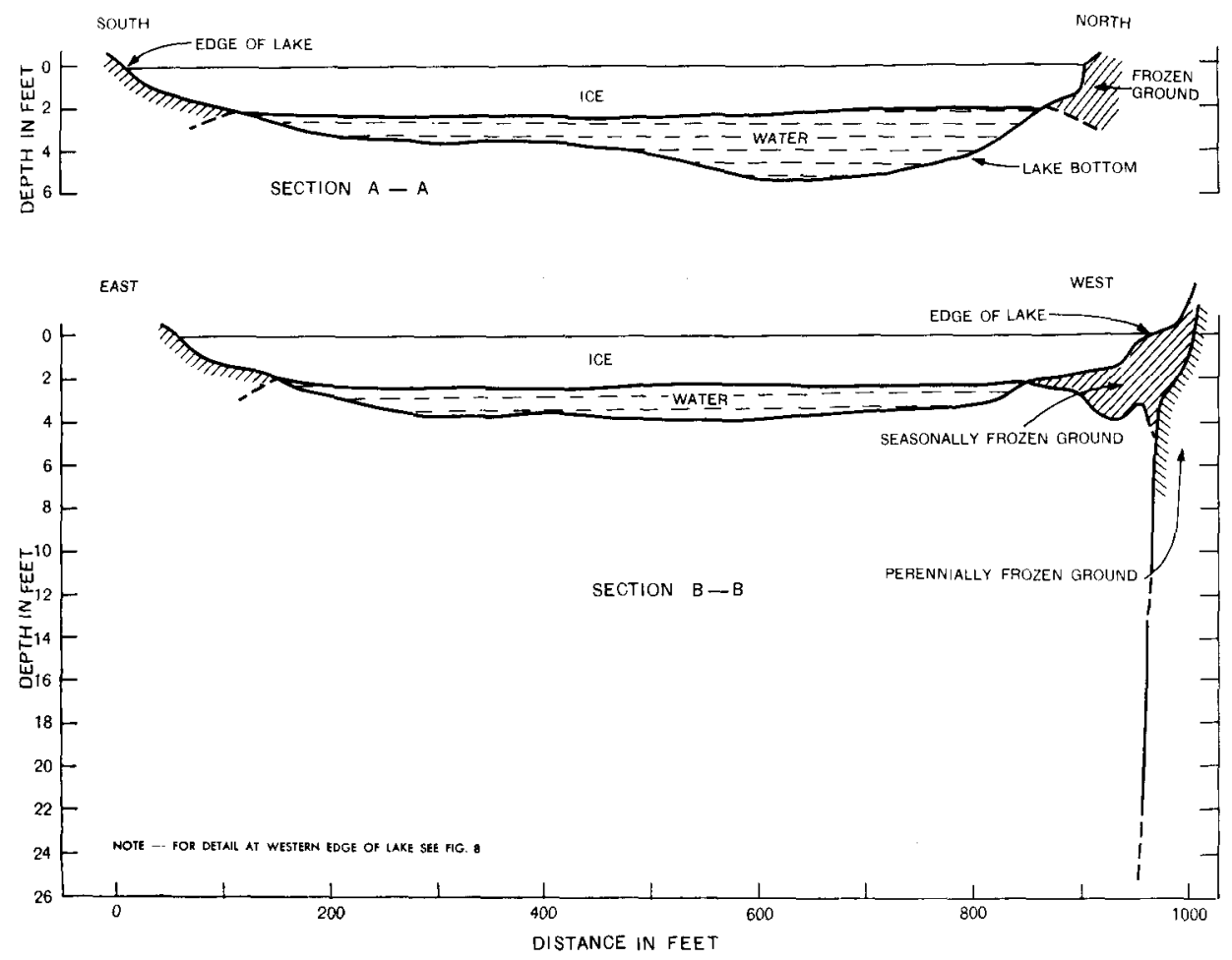

Fig. 6. Typical sections through lake.

The minimum ground temperature was about $14^{\circ} \mathrm{F}$. and occurred at about the 10-foot depth in the holes located on the bank of the lake. When drilling with water, the fluid carrying the bit cuttings to the surface froze on the wall of the holes, particularly between the 12-foot depth and the ground surface. Hot water was circulated periodically to keep the hole free of ice. If left standing, the water in the hole would be solidly frozen to depths exceeding $20 \mathrm{ft}$. within $6 \mathrm{hr}$. 
Double-tube core barrels were used to obtain undisturbed cores of the perennially frozen ground. Two-inch diameter cores were taken from the ground surface to a depth of about $100 \mathrm{ft}$. Below this depth 1-inch diameter cores were obtained. No casing was required as the walls of the holes were solidly frozen and no caving occurred. In the hole at the centre of the lake, where no frozen ground was encountered, samples were obtained using a piston-type tube sampler to about $120 \mathrm{ft}$. Below this depth a double-tube core barrel was used to obtain 1-inch diameter cores. This hole had to be cased for its full depth to prevent caving of the wall.

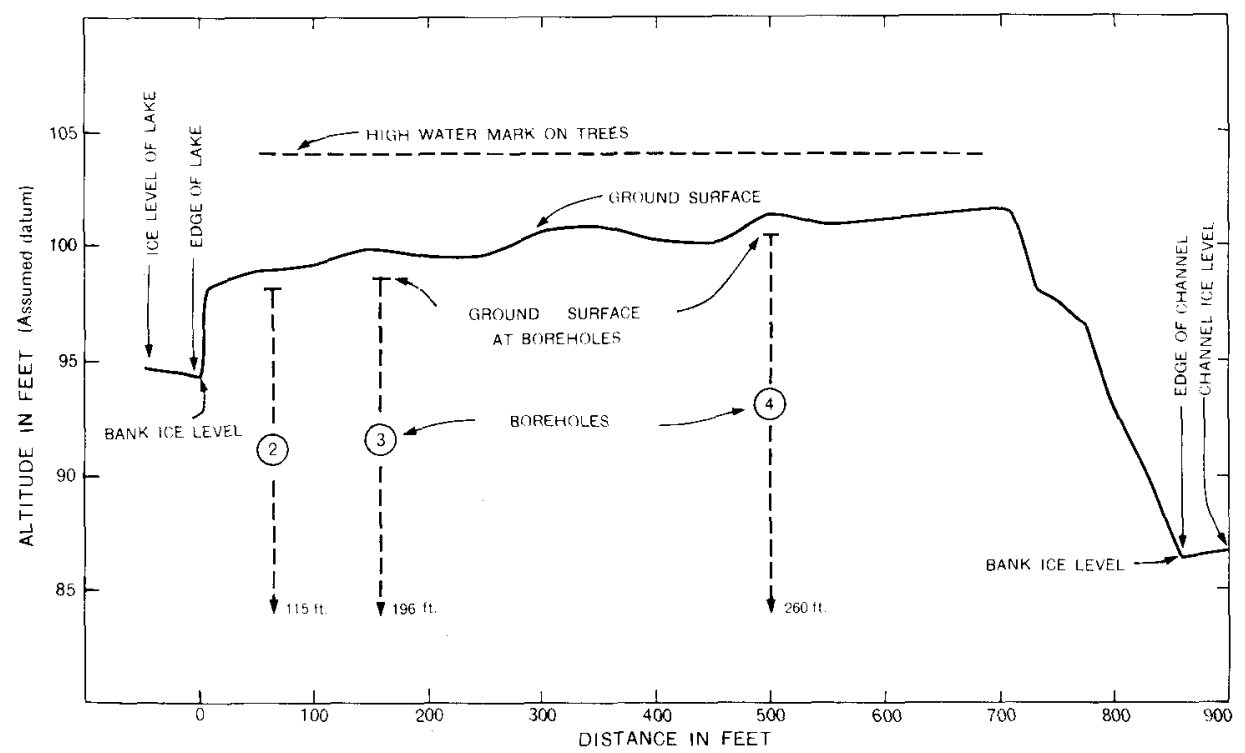

Fig. 7. Ground profile between lake and channel.

\section{Results of the investigation}

\section{Terrain observations}

Surveys were carried out on a $\mathbf{1 0 0}$-foot grid system to determine the ice thickness, water depth, and lake bottom contours. Except for those areas close to the shore where the lake was frozen to the bottom because of shallow water, the ice cover thickness was quite uniform, ranging from $2 \mathrm{ft} .2 \mathrm{in}$. to $2 \mathrm{ft} .6 \mathrm{in}$. and averaging $2 \mathrm{ft} .4 \mathrm{in}$. in thickness. The water depth below the ice cover varied over the lake but averaged between 1.5 and $2 \mathrm{ft}$. The lake bottom contours are shown in Fig. 5 and typical sections showing ice cover thickness and water depth are given in Fig. 6. The snow cover was fairly uniformly about $1 \mathrm{ft}$. deep. Little or no drifting had occurred on the lake as it is relatively small and well sheltered by tree growth.

Level surveys were run on a line between the lake and the delta channel nearby to determine relative altitudes. The ground profile is shown in Fig. 7, 
as well as the approximate high-water flood altitude as observed from marks on trees. Flooding of the ground surface during spring break-up apparently occurs at intervals of a few years but probably not every year. Previous flooding is indicated by two features. Firstly, the moss cover is very thin (about 1 in.) and poorly developed due to flood-deposited material that killed or hindered its growth. Secondly, silt marks on trees indicate an extreme high water mark about $5 \mathrm{ft}$. above the present ground surface, i.e., about $20 \mathrm{ft}$. above the winter ice level of the adjacent delta channel. Nearrecord high water levels occurred in the Mackenzie Delta during break-up (early June) in both 1961 and 1962.

The largest trees at the site were spruce, growing to a height of about $40 \mathrm{ft}$. right on the edge of the lake. These were up to $12 \mathrm{in.}$ in diameter and were as much as 220 years old.

\section{Soil profile}

Undisturbed soil samples were obtained for most of the full depth of holes Nos. 1 and 3 and at various intervals in the other two holes. Standard engineering tests were run on representative samples to identify and classify soils encountered. The typical soil profile at this locality in the delta is as follows:

$$
\begin{aligned}
0 \text { to } 100 \mathrm{ft} \text { - - thinly stratified sandy silt with layers of decomposed organic } \\
\text { material throughout. The content of organic material was } \\
\text { particularly high at the bottom of this layer. } \\
100 \text { to } 180 \mathrm{ft} \text {. - a fine to medium sand with thin layers of organic material, } \\
\text { spaced at irregular intervals throughout the full depth. } \\
180 \text { to } 230 \mathrm{ft} \text {. - very dense clay containing scattered small pebbles from } \\
\\
206 \text { to } 221 \mathrm{ft} \text { and a high concentration of pebbles in the } \\
\text { bottom } 9 \mathrm{ft} \text {. above bedrock. No pebbles were found in the } \\
\text { top } 26 \mathrm{ft} \text {. of the clay layer. } \\
230 \mathrm{ft} \text { - } \text { bedrock (dolomitic limestone). }
\end{aligned}
$$

\section{Permafrost}

The drilling and sampling operations showed that the sediments below the centre of the lake (hole No. 1) were unfrozen to bedrock, encountered at a depth of $230 \mathrm{ft}$. On the other hand, permafrost did occur for the full depth of each of the three holes west of the lake, i.e., to a depth of at least $115 \mathrm{ft}$. in hole No. 2, $196 \mathrm{ft}$. in hole No. 3 and $260 \mathrm{ft}$. (bedrock) in hole No. 4.

Visible ice segregation in the form of horizontal and irregularly oriented layers was confined mostly to the top $30 \mathrm{ft}$. of the perennially frozen soils encountered. Below this depth the soils were solidly frozen but only random thin ice layers, occurring in predominantly silty or clayey soils, were noted. Sandy material was well bonded by ice not visible to the eye.

Ground temperature measurements were made in May 1961 at each of the thermocouple cables installed to depths of 100 and $200 \mathrm{ft}$. in holes Nos. 3 and 4 respectively. The results of these observations are plotted in Fig. 8. Although the ground thermal regime would not have returned to 
equilibrium following disturbance by the drilling operation, the effect on the ground temperature measurements would be relatively small and they are therefore believed to be fairly representative of actual conditions.

Hand probings made from the ice surface near the western edge of the lake in April 1961 and on the shore in late September 1962 showed that the permafrost table sloped steeply down at the edge of the lake. The edge of the lake is not well defined because of the very shallow depth of water occurring for some distance out from the shore. At the edge of the lake (as defined by the edge of the ice cover in April 1961 which agreed exactly with the water's edge in September 1962) the permafrost table was at a depth of $8.6 \mathrm{ft}$., $8 \mathrm{ft}$. from the bank it was $15.5 \mathrm{ft}$. below the ice surface, $10 \mathrm{ft}$. from the bank - at a depth of $19.7 \mathrm{ft}$. - and, at $13 \mathrm{ft}$., was greater than $22 \mathrm{ft}$. below the ice. At each of the three last-noted localities, the water (ice) depth was only about $0.3 \mathrm{ft}$. The location of the permafrost table is shown on a detailed section of the west edge of the lake (Fig. 9).

Fig. 8. Ground temperatures, boreholes Nos. 3 and 4 (May 1961).

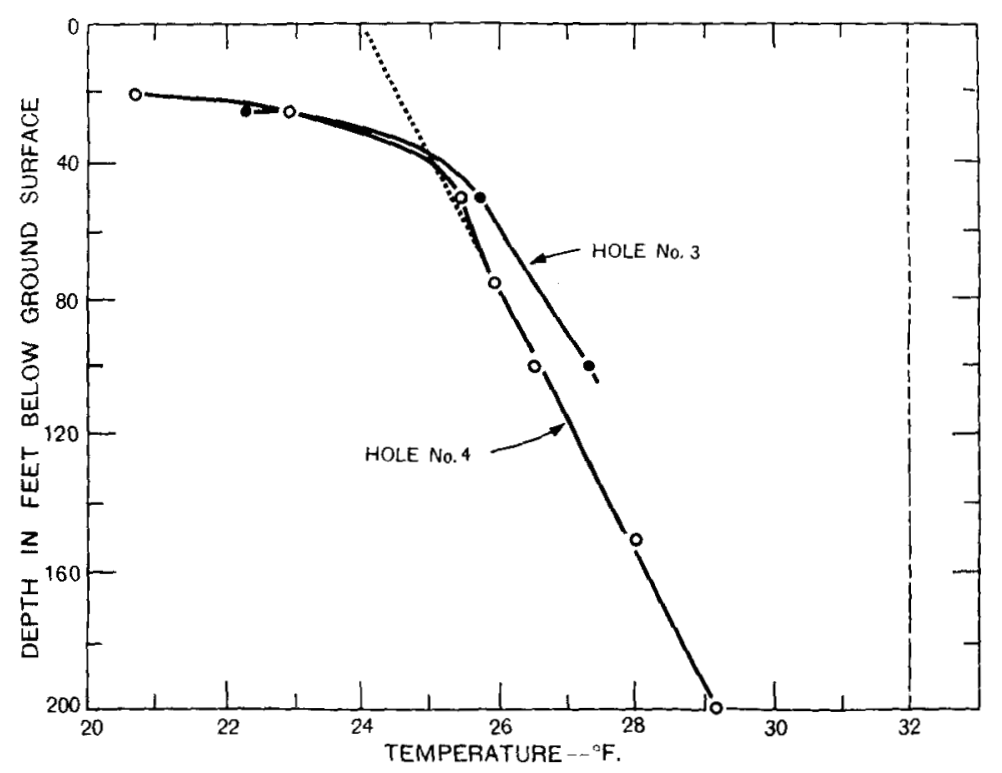

\section{Discussion of results}

It is evident that the lake, although quite small and shallow, has a very marked influence on the distribution of permafrost. The thawing effect of the lake is confined, however, to the ground lying under the lake as indicated by the presence of permafrost at the shoreline, but the thermal effect of the lake extends into the surrounding area for some distance away from 
as well as the approximate high-water flood altitude as observed from marks on trees. Flooding of the ground surface during spring break-up apparently occurs at intervals of a few years but probably not every year. Previous flooding is indicated by two features. Firstly, the moss cover is very thin (about $1 \mathrm{in}$.) and poorly developed due to flood-deposited material that killed or hindered its growth. Secondly, silt marks on trees indicate an extreme high water mark about $5 \mathrm{ft}$. above the present ground surface, i.e., about $20 \mathrm{ft}$. above the winter ice level of the adjacent delta channel. Nearrecord high water levels occurred in the Mackenzie Delta during break-up (early June) in both 1961 and 1962.

The largest trees at the site were spruce, growing to a height of about $40 \mathrm{ft}$. right on the edge of the lake. These were up to $12 \mathrm{in}$. in diameter and were as much as 220 years old.

\section{Soil profile}

Undisturbed soil samples were obtained for most of the full depth of holes Nos. 1 and 3 and at various intervals in the other two holes. Standard engineering tests were run on representative samples to identify and classify soils encountered. The typical soil profile at this locality in the delta is as follows:

$\begin{aligned} & 0 \text { to } 100 \mathrm{ft} \text {. - } \text { thinly stratified sandy silt with layers of decomposed organic } \\ & \text { material throughout. The content of organic material was } \\ & \text { particularly high at the bottom of this layer. } \\ & 100 \text { to } 180 \mathrm{ft} \text {. - a fine to medium sand with thin layers of organic material, } \\ & \text { spaced at irregular intervals throughout the full depth. } \\ & 180 \text { to } 230 \mathrm{ft} \text {. - very dense clay containing scattered small pebbles from } \\ & \\ & \text { 206 to } 221 \mathrm{ft} \text {. and a high concentration of pebbles in the } \\ & \text { bottom } 9 \mathrm{ft} \text {. above bedrock. No pebbles were found in the } \\ & \text { top } 26 \mathrm{ft} \text { of the clay layer. } \\ & 230 \mathrm{ft} \text {. - bedrock (dolomitic limestone). }\end{aligned}$

\section{Permafrost}

The drilling and sampling operations showed that the sediments below the centre of the lake (hole No. 1) were unfrozen to bedrock, encountered at a depth of $230 \mathrm{ft}$. On the other hand, permafrost did occur for the full depth of each of the three holes west of the lake, i.e., to a depth of at least $115 \mathrm{ft}$. in hole No. 2, $196 \mathrm{ft}$. in hole No. 3 and $260 \mathrm{ft}$. (bedrock) in hole No. 4.

Visible ice segregation in the form of horizontal and irregularly oriented layers was confined mostly to the top $30 \mathrm{ft}$. of the perennially frozen soils encountered. Below this depth the soils were solidly frozen but only random thin ice layers, occurring in predominantly silty or clayey soils, were noted. Sandy material was well bonded by ice not visible to the eye.

Ground temperature measurements were made in May 1961 at each of the thermocouple cables installed to depths of 100 and $200 \mathrm{ft}$. in holes Nos. 3 and 4 respectively. The results of these observations are plotted in Fig. 8. Although the ground thermal regime would not have returned to 
equilibrium following disturbance by the drilling operation, the effect on the ground temperature measurements would be relatively small and they are therefore believed to be fairly representative of actual conditions.

Hand probings made from the ice surface near the western edge of the lake in April 1961 and on the shore in late September 1962 showed that the permafrost table sloped steeply down at the edge of the lake. The edge of the lake is not well defined because of the very shallow depth of water occurring for some distance out from the shore. At the edge of the lake (as defined by the edge of the ice cover in April 1961 which agreed exactly with the water's edge in September 1962) the permafrost table was at a depth of $8.6 \mathrm{ft}$., $8 \mathrm{ft}$. from the bank it was $15.5 \mathrm{ft}$. below the ice surface, $10 \mathrm{ft}$. from the bank - at a depth of $19.7 \mathrm{ft}$. - and, at $13 \mathrm{ft}$., was greater than $22 \mathrm{ft}$. below the ice. At each of the three last-noted localities, the water (ice) depth was only about $0.3 \mathrm{ft}$. The location of the permafrost table is shown on a detailed section of the west edge of the lake (Fig. 9).

Fig. 8. Ground temperatures, boreholes Nos. 3 and 4 (May 1961).

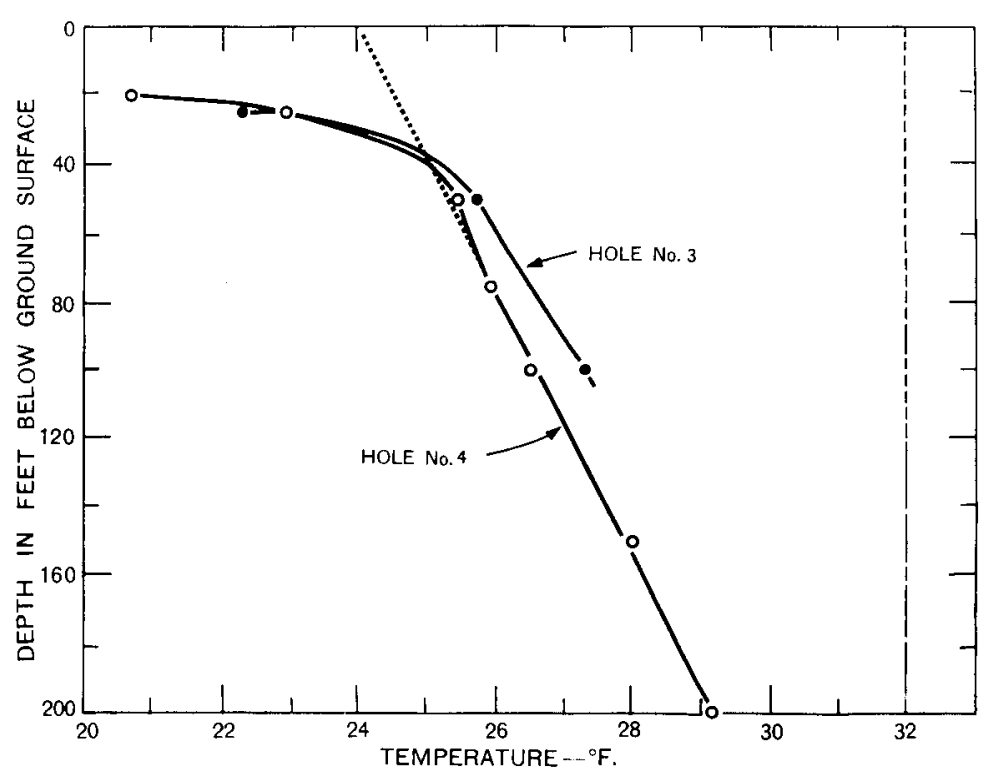

\section{Discussion of results}

It is evident that the lake, although quite small and shallow, has a very marked influence on the distribution of permafrost. The thawing effect of the lake is confined, however, to the ground lying under the lake as indicated by the presence of permafrost at the shoreline, but the thermal effect of the lake extends into the surrounding area for some distance away from 
the shore according to the ground temperature observations. Extrapolation of the two temperature profiles (Fig. 8), assuming a uniform gradient, produces a thickness of permafrost of about $250 \mathrm{ft}$. at hole No. 3 (132 ft. west of the lake) and about $300 \mathrm{ft}$. at hole No. 4 (550 ft. west of the lake). It is assumed that the permafrost "shelves" under the edge of the lake in the form of a wedge with its base curving back and downwards under the shoreline.

The location of the permafrost table under and about this lake depends on a number of factors, the principal ones being the mean annual water and ground surface temperatures and the geothermal gradient for the region. The constancy of the size and shape of the lake with the passage of time is also important.

Several features of the lake support the assumption that the present characteristics of the lake have prevailed for a long time. The shoreline appears to be stable as evidenced by the presence of trees as old as 220 years. No significant slumping due to thawing was observed around the edge of the lake. High-water levels resulting from ice damming in the main delta channels during spring floods normally last only 4 or 5 days, and therefore would have little effect on the thermal regime of the ground. Deposition of a thin layer of sediments is the main result of such floods.

Observations of ice thickness and water depth in the spring of 1961 suggest that it is unlikely that the lake freezes to the bottom, even during the most severe winter. During the winter of 1960-61, air temperatures and snowfall were below normal, a situation conducive to formation of thick ice in lakes. Nevertheless, the lake, although only about $5 \mathrm{ft}$. deep, was not frozen to the bottom. As a result, a layer of water is continuously in contact with the underlying sediments, thus maintaining them in a thawed condition, i.e., the lake has a mean bottom temperature higher than $32^{\circ} \mathrm{F}$.

To predict the position of the permafrost table it is necessary to know the actual water and ground temperatures with considerable accuracy. Unfortunately, because of access and other difficulties, the scope of the investigation did not include a program to measure these factors. Calculations have been made, however, to analyze the thermal situation at this lake assuming steady state conditions (Brown, Johnston, Brown). This analysis, which takes into account the effect introduced by surrounding bodies of water, indicates that the entire region under the lake is unfrozen and that the unfrozen zone probably has an "hour-glass" shape.

\section{Conclusions}

The main conclusions, which can be drawn from the observations made, regarding the effect of the lake on the distribution of permafrost are as follows. The existence of the lake has caused the formation and maintenance of a deep thawed zone under this body of water. The thawing effect of the lake is confined to the ground lying under the lake as evidenced by the 


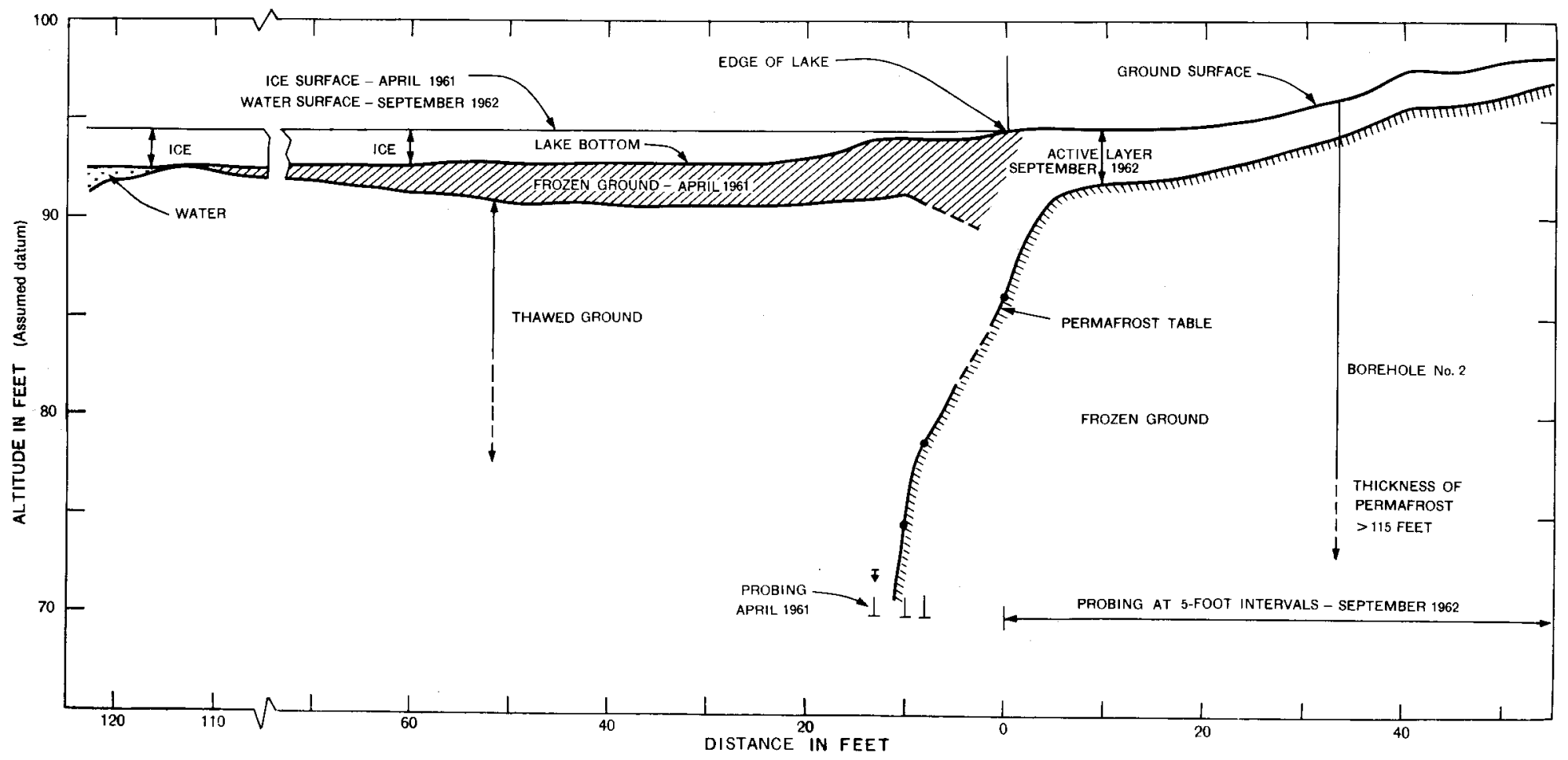

Fig. 9. Profile of permafrost table at edge of lake. 
presence of permafrost at the shoreline. Nevertheless, the ground temperatures measured inland from the shore indicate that the thermal effect of the lake extends for some distance beyond its perimeter.

This paper is a contribution from the Division of Building Research, National Research Council, Canada and is published with the approval of the Director of the Division.

\section{References}

Brewer, Max C. 1958a. The thermal regime of an arctic lake. Trans. Am. Geophys. U. 39:278-84.

1958b. Some results of geothermal investigations of permafrost in northern Alaska. Trans. Am. Geophys. U. 39:19-26.

Brown, W. G. 1963a. Simple graphical methods for estimating the location of permafrost under shallow lakes and rivers. N.R.C. Associate Committee on Soil and Snow Mechanics, Proc., First Can. Conf. on Permafrost. Tech. Memorandum No. 76, pp. 226-31.

1963b. The temperature under heated or cooled areas on the ground surface. Engineering Institute of Canada Transactions, Series B, EIC-63-Mech. 3.

1963c. Graphical determinations of temperature under heated or cooled areas on the ground surface. National Research Council, Canada, Division of Building Research, Tech. Pap. 163, 58 pp.

Brown, W. G., G. H. Johnston, and R. J. E. Brown. Comparison of observed and calculated ground temperatures with permafrost distribution under a northern lake. (In preparation)

Grigor'ev, N. F. 1959. On the influence of water basins on geocryologic conditions of the coastal lowland of the Yana River mouth region of the Yakut ASSR. Izd. Ak. Nauk SSSR. pp. 202-206 (in Russian).

Lachenbruch, Arthur H. 1957a. Thermal effects of the ocean on permafrost. Bull. Geol. Soc. Am. 68:1515-30.

1957b. Three-dimensional heat conduction in permafrost beneath heated buildings. U.S. Geol. Surv. Bull. 1052B, pp. 51-69.

Lachenbruch, A. H., et al. 1962. Temperatures in permafrost. In Temperature - Its measurement and control in science and industry. Vol. III, Part. I. New York: Reinhold Publishing Corp.

Mackay, J. R. 1962. Pingos of the Pleistocene Mackenzie Delta Area, Canada, Dept. of Mines and Technical Surveys, Geographical Branch, Geographical Bull. No. 18, November 1962, pp. 21-63. 